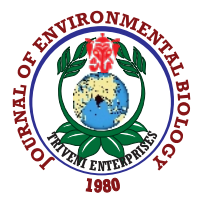

\title{
Yield sustainability of pearl millet and soil biological health with organic and inorganic fertilizer in arid environment
}

\author{
N.R. Panwar*, A. Saxena, D.V. Singh and P. Kumar \\ Division of Integrated Farming System, ICAR - Central Arid Zone Research Institute, Jodhpur-342 003, India \\ *Corresponding Author Email : npanwar_soil@yahoo.com
}

\begin{abstract}
Aim: To assess sustainable yield levels and manure and/or urea needed to sustain in arid zone.

Methodology: A field experiment was conducted over a period of 25 years in arid soils of Jodhpur with three levels of manure $\left(0,2.5\right.$ and 5.0 tha $\left.^{-1} \mathrm{yr}^{-1}\right)$, urea $(0,20$ and $40 \mathrm{~kg} \mathrm{~N}$ $\left.\mathrm{ha}^{-1} \mathrm{yr}^{-1}\right)$ and their combinations to assess the rate of change in yield of pearl millet cultivated with manure and/or urea; minimum quantity of manure and/or urea to be applied for achieving yield stability and minimum quantity of manure and/or urea to be applied for improved soil biological health vis-a-vis yield sustainability.
\end{abstract}

Results: Application of fertilizers over the years showed significant impact on the status of soil organic carbon (SOC) and soil fertility, which in turn influenced sustainability. The results showed that SOC had significant effect on sustainable yield index (SYI). However, available soil $\mathrm{N}$ status did not much influence the SYI. Application of urea-N alone or even that of 2.5 ton manure alone is not adequate to achieve agronomic sustainability of yield.

Interpretation: Integration of FYM @ $2.5 \mathrm{t} \mathrm{ha}^{-1} \mathrm{yr}^{-1}$ with $20 \mathrm{~kg} \mathrm{~N}^{-1}{ }^{-1}$ sustained higher productivity to self-effacing economic status for farmers in a fragile ecosystem with the available minimum resources for livelihood and also sustain soil biological health of arid soils.

Key words: Arid soil, Organic fertilizer, Pearl millet, Soil organic carbon

\section{Abstract}

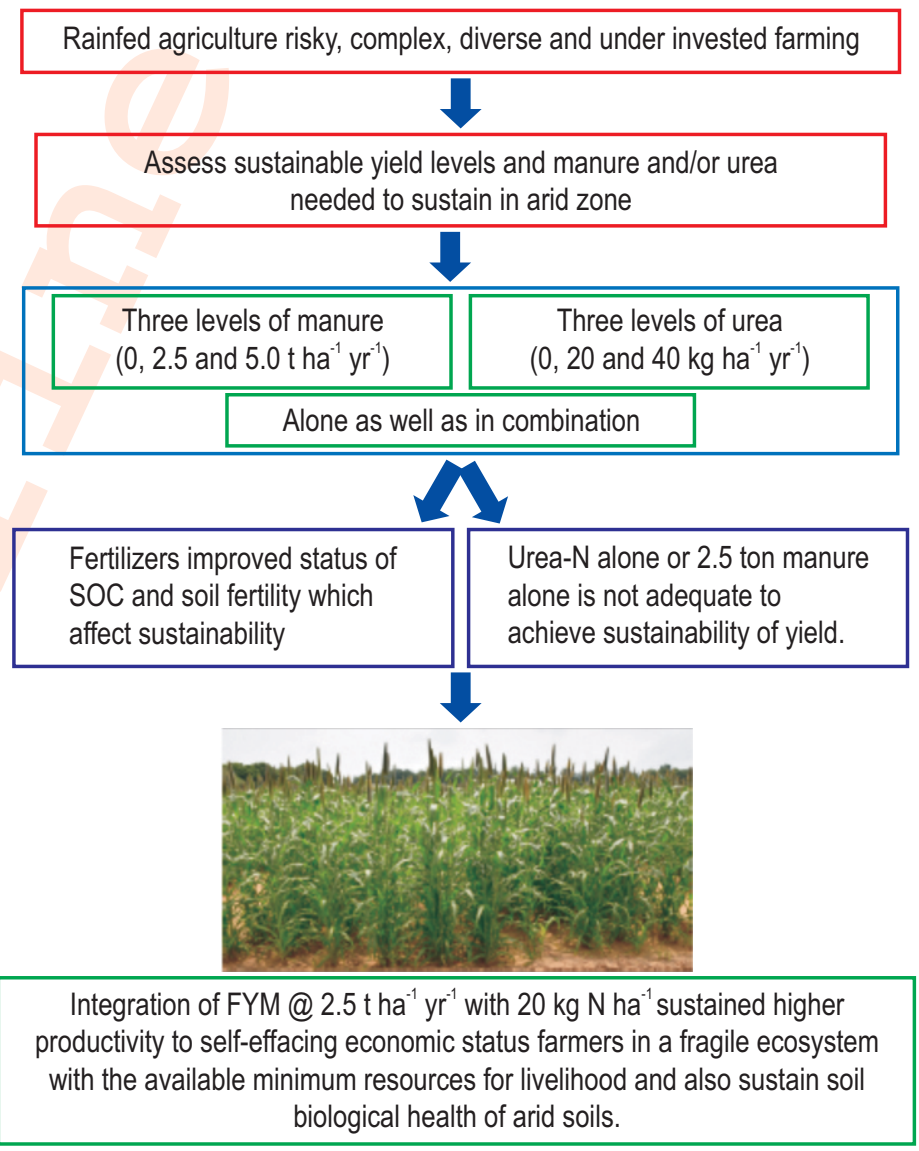

How to cite : Panwar, N.R., A. Saxena, D.V. Singh and P. Kumar: Yield sustainability of pearl millet and soil biological health with organic and inorganic fertilizer in arid environment. J. Environ. Biol., 41, 1724-1734 (2020). 


\section{Introduction}

The use of fertilizer is meagre and largely limited to nitrogenous fertilizer in arid region. Soil organic carbon (SOC) turnover is of principal importance for sustaining soil quality and long-term productivity of agricultural systems. The continuous long-term use of chemical fertilizer has led to many unexpected effects. For example, the productivity-cost does not scale linearly and results in a huge waste of mineral resources (Ye et al., 2020). Modern conventional food production shows sign of production stagnation, resource depletion, and stress on the environment (Stocking, 2003; Moore, 2010). Chemical and organic fertilizers are the most common source applied to improve soil productivity and yield sustainability. Farmyard manure is a major source of soil organic matter and remains the main organic fertilizer. Organic fertilizers have a greater impact on the microbial community structure than chemical fertilizers (Wei et al., 2017). Manures and fertilizers have similar and large effects on the long-term productivity of soils. Organic fertilization is more complicated than application of mineral fertilizers with exactly known nutrient content. Animal manures have been widely used as fertilizers for centuries. Organic fertilizers not only contain the basic nutrients required by crops but also trace elements. Organic matter is an important component of organic fertilizers, and organic acids contained in organic matter can acidify nutrients improving their effectiveness (Tripathi et al., 2014). The fertilization value of organic manures to soil can be improved when suitable alertness is given to the composition and decisions on rates, timing and placement (Schröder, 2005). In contrast to nutrients in organic manures, which have to be released by microbiological processes to make them available to plants, the nutrients in inorganic fertilizers can be directly taken up by plants (Böhme et al., 2005).

Soil microbial biomass and enzymes activity in the rhizosphere are bio-indicators of soil biological health (Antonious et al., 2020). Mineralization of organic matter in soil is carried out by large community of microorganisms and involves a wide range of metabolic processes. Positive correlation between the activity of soil enzymes and nutrient mineralization has been reported in agricultural soils (Shi, 2011). Crop production based on the use of organic manures rather than chemical fertilizers is assumed to be a more sustainable type of agriculture (Chang et al., 2007).

Globally, $84 \%$ of farms are $\leq 2 \mathrm{ha}$, with $72 \%$ of them $\leq 1$ ha (Lowder et al., 2016). Smallholder households (1.5 billion) who live in low-income countries provide food for 2.5 billion people (FAO, 2012), which highlighted their potential to impact food supplies. Pearl millet is traditionally a dry land crop, cultivated mostly in trivial environments of arid and semi-arid tropics of South Asia, Africa and Latin America, characterized by low rainfall, sandy soils with low fertility. Rainfed agriculture having tremendous utilizable technological potential is expected to improve and sustain food, nutritional and livelihood securities. Pearl millet ranks first under the category of millets in India, in terms of area, production and productivity. Due to variations in rainfall yield vary from 4 to 9 times of long-term normal yield in arid zone. Millets are generally grown on less fertile soils, but respond well to fertilizer (Saxena et al., 2018). They can use residual nutrients and, therefore, may not need the levels of fertilization required by other rainy season cereals. Moreover, rainfall plays a major role in soil productivity and yield sustainability in this region. Thus, it is tricky to measure sustainable yield levels and manure and/or urea needed to sustain them. A field experiment was carried out from 1993 to 2017 to find out the rate of change in yield of pearl millet cultivated with manure and/or urea minimum quantity of manure and/or urea to be applied for achieving yield stability and minimum quantity of manure and/or urea to be applied for improved soil biological health vis-a-vis yield sustainability.

\section{Materials and Methods}

Study area: The experiment was conducted at Central Arid Zone Research Institute, Jodhpur (Latitude 26 ${ }^{\circ} 18^{\prime} \mathrm{N}$, Longitude $73^{\circ} 01^{\prime} 30$ "E) during 1993-2017 in soil with pH 8.0, EC 0.319 dS m ${ }^{-1}$, organic carbon $1.14 \mathrm{~g} \mathrm{~kg}^{-1}$, total nitrogen $0.3 \mathrm{~g} \mathrm{~kg}^{-1}$, available phosphorus $14.6 \mathrm{~kg} \mathrm{ha}^{-1}$ and available potassium $225 \mathrm{~kg} \mathrm{ha}^{-1}$. The moisture content at field capacity and permanent wilting point (-15 bar) was 10.5 and $3.4 \%$, respectively. The bulk density of $1 \mathrm{~m}$ soil was $1.541 \mathrm{Mg} \mathrm{m}^{-3}$. The soil contained $86.2 \%$ sand, $8.1 \%$ silt and $5.5 \%$ clay. The region is characterized by a monsoon climate with wet season occurring from the end of June to September. About $95 \%$ of average annual precipitation of $360 \mathrm{~mm}$ is received during this period.

Weather (1993-2017): Annual rainfall from 1993 to 2017 varied from $33.1 \mathrm{~mm}$ in 2002 to $572.2 \mathrm{~mm}$ in 2016 with mean annual rainfall being $364.6 \mathrm{~mm}$. No crop was sown in 2002 due to extremely low rainfall. Rainfall distribution was uni-modal with peaks in July or August (Fig. 1). The mean daily maximum and minimum temperature recorded was $29.0^{\circ} \mathrm{C}$ and $16.6^{\circ} \mathrm{C}$, respectively. The average annual potential evaporation during experimental period was $2615.87 \mathrm{~mm}_{\text {year }}{ }^{-1}$ with weekly peak being recorded in the month of June (Fig. 2).

Treatments: Pearl millet was continuously cultivated without fertilizer/manure (control) (1), and with application of $20 \mathrm{~kg}$ urea-N $\mathrm{ha}^{-1}(2), 40 \mathrm{~kg}_{\text {urea-N ha }}{ }^{-1}(3), 2.5$ ton manure ha- ${ }^{-1}(4), 2.5$ ton manure ha ${ }^{-1}$ along with $20 \mathrm{~kg}$ urea-Nha- ${ }^{-1}(5), 2.5$ ton manure ha ${ }^{-1}$ along with $40 \mathrm{~kg}$ urea-N ha-1 (6), 5.0 ton manure ha- ${ }^{-1}(7), 2.5$ ton manure ha-1 along with $20 \mathrm{~kg}$ urea-Nha-1 (8), 5.0 ton manure ha ${ }^{-1}$ along with $40 \mathrm{~kg}$ urea-Nha ${ }^{-1}$ (9). Experiment was laid out in randomized block design and replicated four times. Row to row and plant to plant spacing was kept at 60 and $15 \mathrm{~cm}$, respectively. The crops were sown after the onset of monsoon every year. Variety $\mathrm{MH}-179$ (grain yield potential 2.2 tons ha ${ }^{-1}$, stover yield 


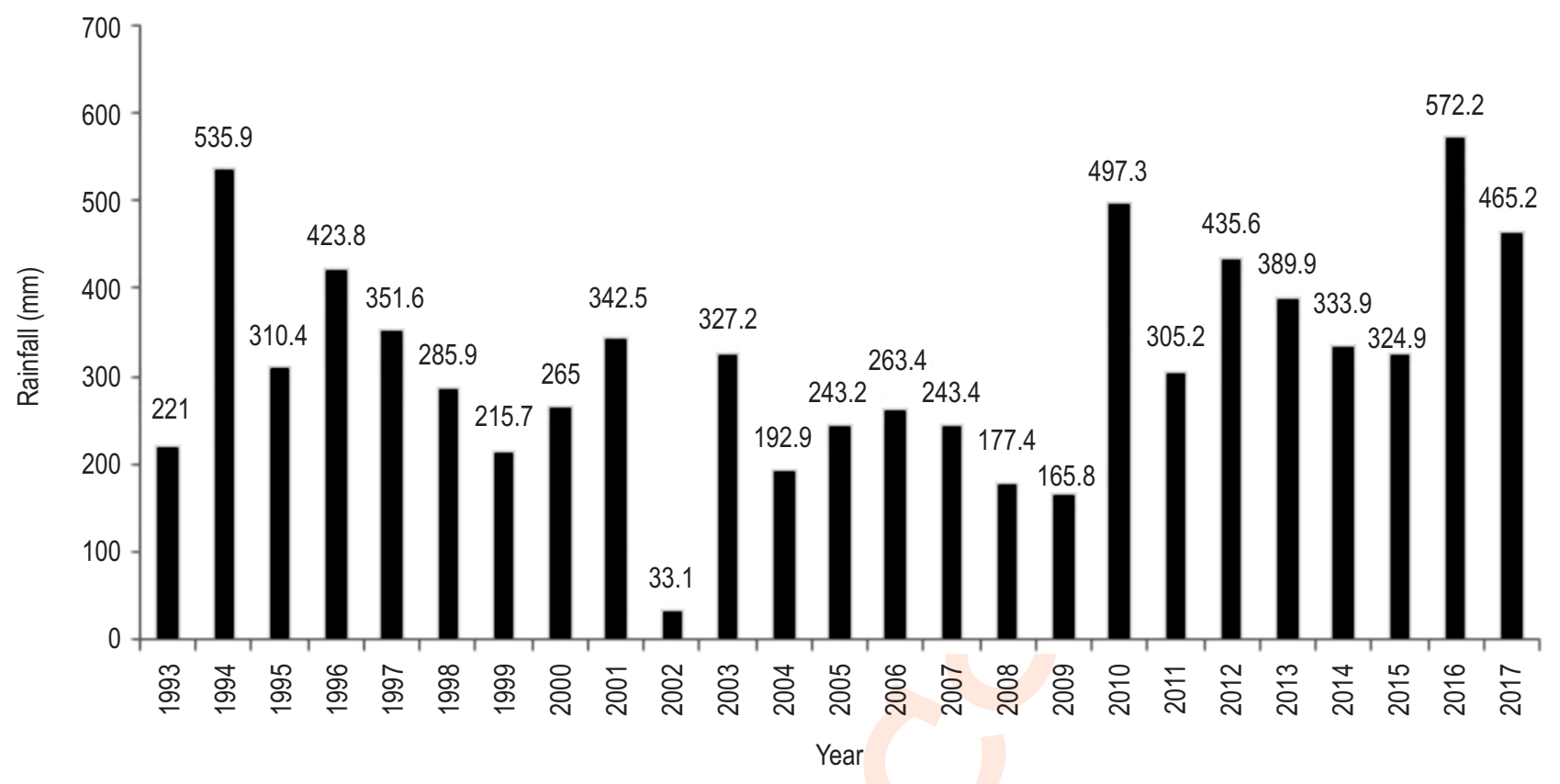

Fig. 1 : Rainfall during each cropping season, assessed by summation of rainfall from date of sowing till harvest.

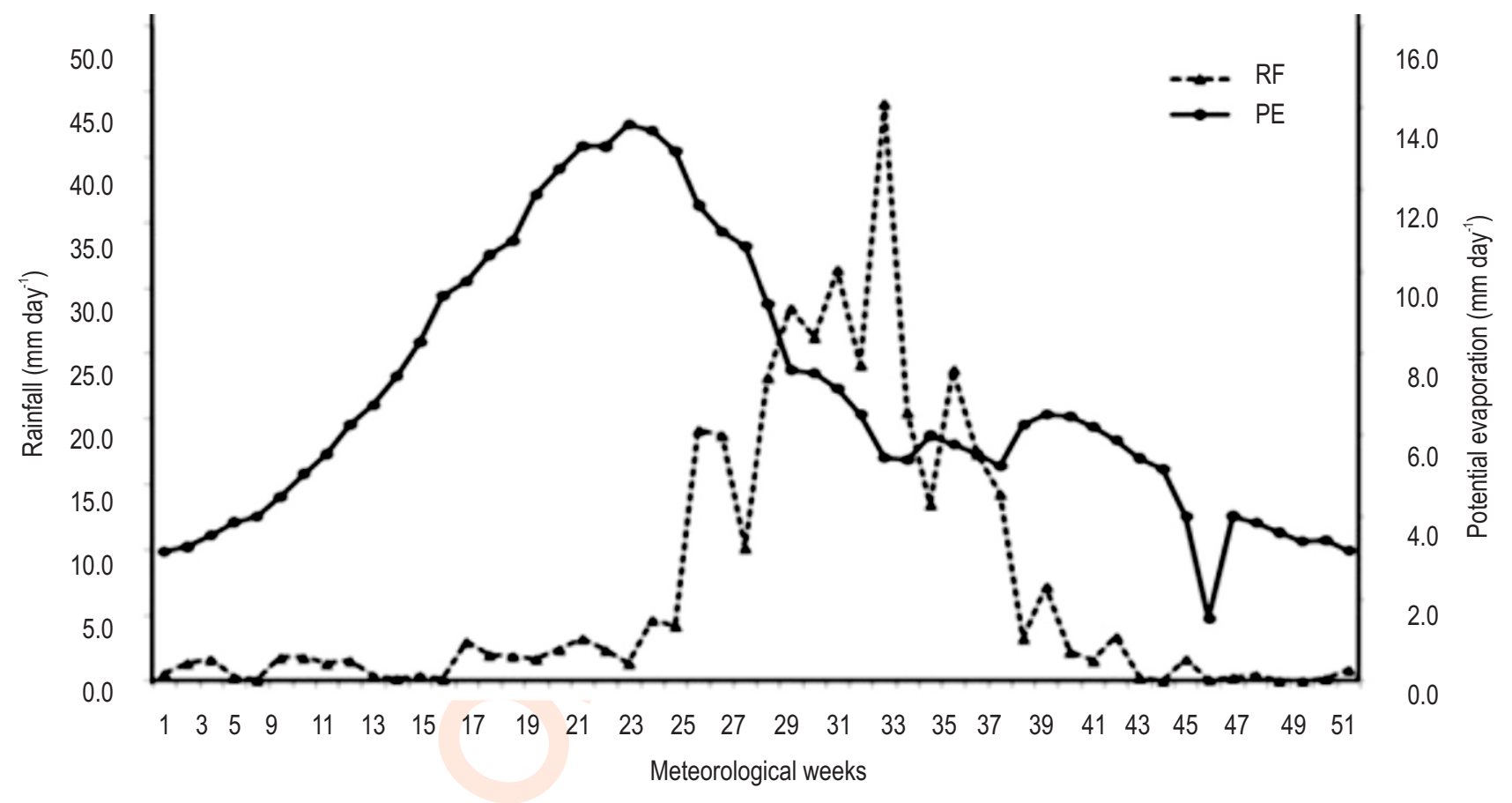

Fig. 2 : Mean weekly rainfall and potential evaporation averaged over the period 1993-2017.

potential 5.8 tons ha ${ }^{-1}$, maturity period 84 days, year of release 1986) was grown from 1993 to 2000 . This variety was de-notified in 2000 due to high incidences of diseases and was replaced with HHB-67 (grain yield potential 3.1 ton ha ${ }^{-1}$, stover yield potential 8.8 ton ha ${ }^{-1}$, maturity period 62 days, year of release 1986) in year 2001. Manure was applied before sowing and urea was applied in two equal doses as basal and after rainfall that occurred after 4 weeks of sowing. Inter-culture operations were carried out after 3 and 6 weeks of sowing. Whole plots were harvested in October each year. Pearl millet grain yields were expressed at $12 \%$ moisture basis. Lay-out of experiment was not changed during the entire experimental period. Average composition of manure 
was $29.2 \% \mathrm{C}, 1.4 \% \mathrm{~N}, 146.0 \mu \mathrm{g} \mathrm{Pg}{ }^{-1}, 108.9 \mu \mathrm{Zn} \mathrm{g}{ }^{-1}, 328.4 \mu \mathrm{g} \mathrm{Mn}$ $\mathrm{g}^{-1}$ and $21.8 \mathrm{\mu g} \mathrm{Cu} \mathrm{g}^{-1}$.

Soil sampling, preparation, and analysis: After harvesting of pearl millet, soil samples were taken from the surface layer $(0-15$ $\mathrm{cm}$ ) in three replicates in October, 2017. Soil samples $(100 \mathrm{~g})$ were sieved $(2 \mathrm{~mm})$ after removing plant material and roots. Half of the samples were air-dried for 3 days and stored at room temperature until chemical analysis. The remaining sieved soil (2 $\mathrm{mm}$ ) was kept at $4^{\circ} \mathrm{C}$ and then analyzed within 2 weeks. All chemical and microbiological results reported are means of three replicates and are expressed on an oven-dry basis. Soil moisture content was determined after drying at $105^{\circ} \mathrm{C}$ for $24 \mathrm{hr}$.

Soil pH and EC were measured in 1:2.5 soil-water suspension (Jackson, 1962). The cation exchange capacity (CEC) of soil was analyzed by method 9081 (USEPA, 1990). Soil was analyzed for oxidizable SOC by the method of Walkley and Black (1934), for total $\mathrm{N}$ by CHNS analyzer (EuroEA3000), Available nitrogen was determined using alkaline potassium permanganate method by Subbiah and Asija (1956), available P extracted from soil using $0.5 \mathrm{M}$ sodium bicarbonate by Olsen et al. (1954), and available $\mathrm{K}$ after treatment with $1 \mathrm{~N}$ ammonium acetate and estimation using a flame photometer (Jackson, 1962).

Activity of the following soil enzymes was measured: (a) dehydrogenase, due to its important role in degradation of organic matter and because it is a general indicator of soil enzymatic activity; (b) $\beta$-glucosidase, due to its critical role in releasing lower-molecular-weight sugars (important energy sources of micro-organisms) and (c) hydrolysis of fluorescein diacetate (protease, lipase and esterase), due to their role in releasing of inorganic $\mathrm{N}$ in the $\mathrm{N}$ turnover. Soil enzymes were chosen for their definite role in nutrient transformation. Soil dehydrogenase activity was estimated by reducing 2,3,5triphenyltetrazolium chloride (Casida et al., 1964). B-glucosidase activity was estimated by determining the amount of $p$ nitrophenol released after $1 \mathrm{~h}$ of incubation with $p$-nitrophenyl- $\beta$ $D$-glucopyranoside and $\beta$-galactosidase activity was estimated by determining the amount of $p$-nitrophenol released after $1 \mathrm{hr}$ of incubation with $p$-nitrophenyl- $\beta$-D-galactopyranoside (Eivazi and Tabatabai 1977). Total microbial activity in the soil was estimated by monitoring the hydrolysis of fluorescein diacetate (FDA), as described by Green et al. (2006). Acid and Alkaline Phosphatase activity (PA) was determined by Tabatabai and Bremner (1969). The above analyses were complemented by determining of microbial carbon content (Cmic) in the individual samples using fumigation-extraction method for measuring soil microbial biomass in accordance with Vance et al. (1987).

Fertilizer Manure Ratio (FMR): For each season from 1993 to 2017, the relative effect of fertilizer in comparison to manure was assessed by fertilizer to manure ratio (FMR) for cereal grain yield calculated as follows:

\section{FMR $=$ Yield Fertilizer/Yield Manure}

FMR was assessed for 20 and $40 \mathrm{~kg}$ urea $\mathrm{N}$ against 2.5 and 5 ton manure ha ${ }^{-1}$, respectively.

Sustainability Yield Index (SYI): Sustainability yield index was calculated (Singh et al., 1990; Wanjari et al., 2004) at the end of experiment in 2017 as follows:

SYI= (Average yield during experimental period-Standard Deviation)/maximum achieved yield over the years

Statistical analyses : The basic statistical values, i.e., average and standard deviations (SD) were calculated using Microsoft Excel. Each sample was analyzed in triplicate and the values were averaged. Analysis of variance was done to determine the treatment effects (Gomez and Gomez, 1984). Treatment means were compared at $5 \%$ level of significance $(P<0.05)$ using least significant difference (LSD).

\section{Results and Discussion}

Grain and stover yield (1993-2017): The significant increased grain yield over control after application of $20 \mathrm{~kg}$ urea-N ha ${ }^{-1}$ was recorded in only 10 years out of 25 years of study. But, significant increase in grain yield following application of $40 \mathrm{~kg}$ urea- $\mathrm{N}, 2.5$ ton manure, 2.5 ton manure along with $20 \mathrm{~kg}$ urea-N and 2.5 ton manure along with $40 \mathrm{~kg}$ urea-N ha- ${ }^{-1}$ was recorded in 13, 19, 22 and 23 years respectively. Application of 5 ton manure alone significantly increased grain yield over control in 24 years. Though most treatments significantly increased grain production over control in 24 years but within treatments the differences were not consistently significant. Largely similar trend was observed for stover yield also.

Continuous cropping without and with fertilizer ( $\mathrm{N} 40 \mathrm{~kg}$ $\mathrm{ha}^{-1}$ ) application of pearl millet produced 669 and $1103 \mathrm{~kg}_{\text {grain }} \mathrm{ha}^{-1}$ (Fig. 3). Application of 20 and $40 \mathrm{~kg} \mathrm{~N}^{-1} \mathrm{~A}^{-1}$ significantly increased grain yield (914 and $1103 \mathrm{~kg} \mathrm{ha}^{-1}$ ) over control. Nitrogen applied through organic source or combined source (organic+inorganic) led to further significant improvement in production. Application of $2.5 \mathrm{t}$ and $5 \mathrm{tFYM}$ alone produced 1205 and $1222 \mathrm{~kg}_{\text {grain }} \mathrm{ha}^{-1}$. The maximum grain yield $\left(1705 \mathrm{~kg} \mathrm{ha}^{-1}\right)$ was obtained with the application of $5 \mathrm{tFYM}$ along with $40 \mathrm{~kg} \mathrm{~N} \mathrm{ha}^{-1}$. Sui et al. (2019) also reported that use of organic manure leads to increase in wheat yield. The total grain production of pearl millet during the 25 years of time period was minimum in control and maximum after application of 5 ton manure along with $40 \mathrm{~kg} \mathrm{Nha}^{-1}$ (Fig. 4).

Sustainable Yield Index: The SYI value for actual yield was minimum for control ( 0.10$)$ and maximum following application of 5.0 ton manure. In various treatments it increased in the following order : control $(0.10)<2.5$ ton manure $(0.16)=2.5$ ton manure + 


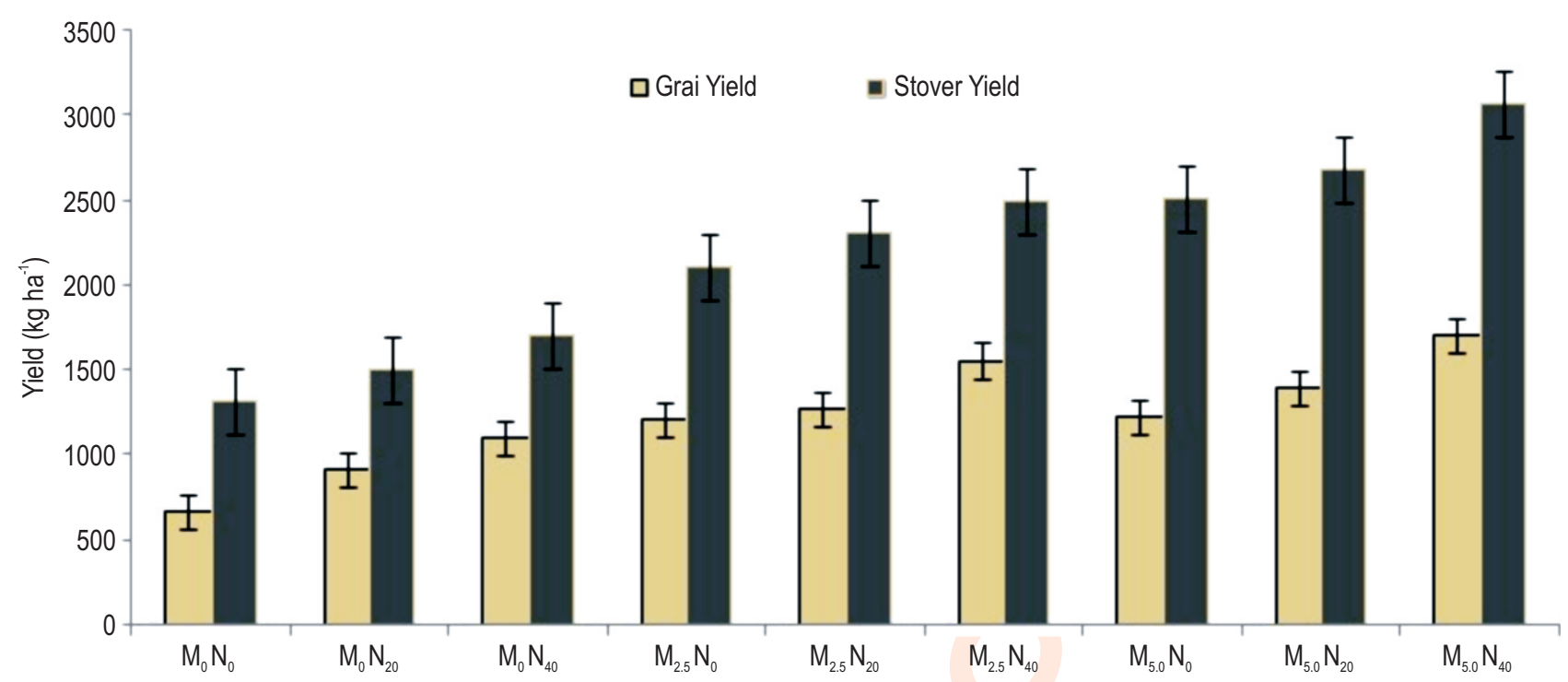

Fig. 3: Grain and stover yield (kg ha"-1) of pearl millet in 2017.

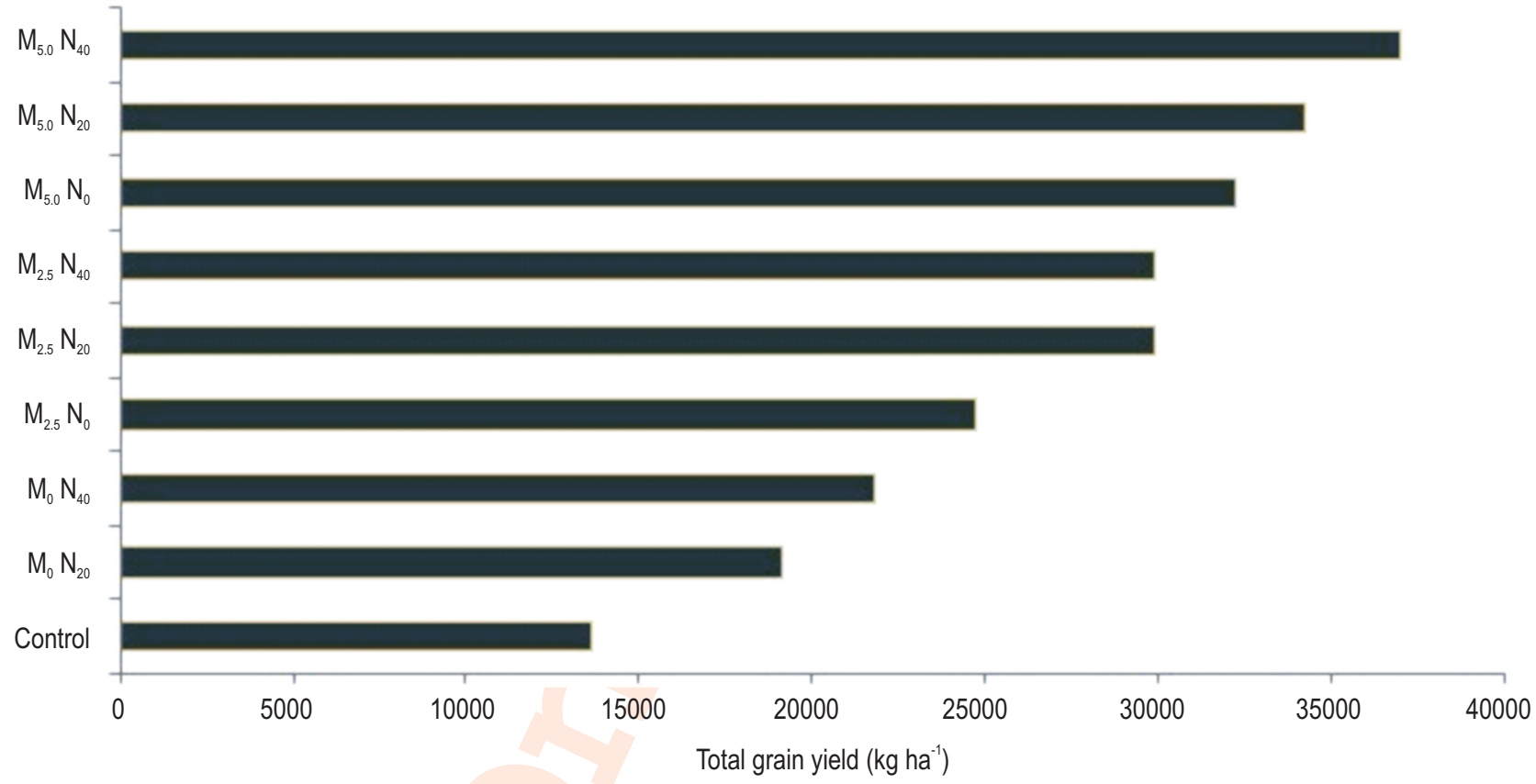

Fig. 4 : Total grain production under different treatments during 25 years of experimental period.

40 kg urea-N ha- ${ }^{-1}(0.16)<20 \mathrm{~kg}$ urea-N ha ${ }^{-1}(0.17)<40 \mathrm{~kg}$ urea-N $\mathrm{ha}^{-1}(0.19)=5$ ton manure $+20 \mathrm{~kg}$ urea- $\mathrm{N} \mathrm{ha}^{-1}(0.19)<2.5$ ton manure $+20 \mathrm{~kg}$ urea-N ha ${ }^{-1}(0.20)=5$ ton manure $+40 \mathrm{~kg}$ urea- $\mathrm{N}$ ha $^{-1}(0.20)<5$ ton manure $(0.21)$.

Stability of yield over the years at same site is a major indicator of agronomic sustainability of a production system (Denison et al., 2004). Manna et al. (2005) reported that yield sustainability can only be achieved by harmonizing the removal and addition of nutrients, which also confirmed from the results above mentioned. Our results clearly indicated that application of urea-N alone or even that of 2.5 ton manure alone is not adequate to achieve agronomic sustainability of yield.

Fertilizer: Manure Ratio (FMR): Amount of $\mathrm{N}$ in 2.5 ton manure was equivalent to $20 \mathrm{~kg}$ urea- $\mathrm{N}$ and in 5.0 ton equivalent to $40 \mathrm{~kg}$ urea-N. Comparing the effect of manure and similar level of urea$\mathrm{N}$ showed that FMR of grain yield decreased with time (Fig. 5). 


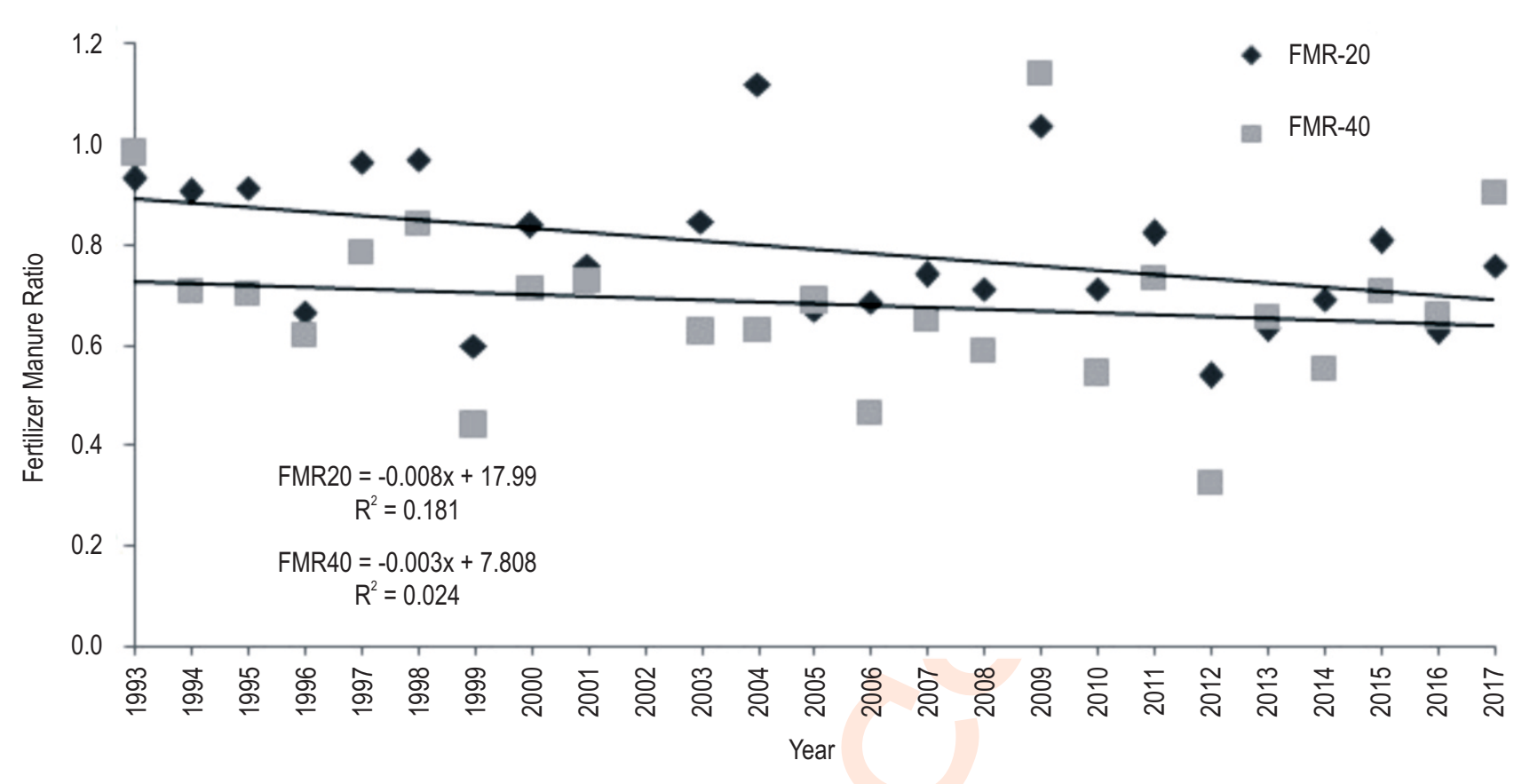

Fig. 5 : Fertilizer: Manure ratio (FMR) of grain yield during experimental period (1993-2017).

The trend was more steeper for FMR of $20 \mathrm{~kg}$ urea-N:2.5 ton manure. Application of urea-N alone or even that of 2.5 ton manure alone is not adequate to achieve agronomic sustainability of yield.

Manure contain most of the nutrients required for plant growth whereas urea has only N, therefore, decline in FMR (Fig. 5) could also be attributed to better replenishment of nutrients. Grain normally takes up more nutrients than of stover in pearl millet as in many other crops (Selvakumari et al., 2000; Tiwari et al., 2001; Singh et al., 2002). It is possible that the nutrients made available through urea or manure were adequate for synthesis of stover and only during grain formation higher nutrients supplied by manure played a role.

\section{Soil nutrient status:}

Soil organic carbon and CEC : Soil organic carbon status increased in all plots at $0-15 \mathrm{~cm}$ soil layer, except in the control plots (Table 1). Application of FYM @ 2.5 and 5 tha $^{-1}$ increased the level of soil organic carbon by 64 and $100 \%$ over initial value (1.14 $\left.\mathrm{g} \mathrm{kg}^{-1}\right)$. The maximum soil organic carbon $\left(2.93 \mathrm{~g} \mathrm{~kg}^{-1}\right)$ was recorded in FYM @ 5 tha $^{-1}+40 \mathrm{~kg} \mathrm{~N} \mathrm{ha}^{-1}$. Regular applications of FYM in combination with $\mathrm{N}$ or alone resulted considerable build up of total SOC at $0-15 \mathrm{~cm}$ soil layer. The higher SOC concentration in the fertilizer + FYM treated plots was a result of increased yields of roots and plant residues, and application of organic carbon through FYM. Considerably higher SOC build up with M5+N40 compared with FYM and nitrogen alone indicated the beneficial effect of balanced fertilization in improving SOC status (Aulakh et al., 2001). An increase in SOC content under manure applications is possibly also due to resourceful metabolic activity of microorganisms and physico-chemical shield of SOC. Katterer et al. (2011) reported higher production of root biomass of crops leading to more organic residue addition to soil. Aoyama and Kumakura (2001) also reported an increase in organic matter in an Ando soil, induced by mineral fertilizer and cattle manure applications.

The cation exchange capacity of soil increased significantly with the application of FYM @ 2.5 and 5 t ha $^{-1}$ (7.13 and 7.47 $\mathrm{Cmol} \mathrm{kg}^{-1}$ ) in comparison to control (6.45). Application of manure or compost increased the CEC of soil by increasing the soil organic matter content and soil carbon content. The effect was probably due to increased fine fraction of soil carbon content (Guibert, 1999). When manure was combined with chemical fertilizer, the stimulation effect on SOC was higher than the application of chemical fertilizer alone. This is expected because manure itself has higher carbon contents, and plant residues and root exudates returned to soils are generally higher under manure treatment (Giacometti et al., 2014).

Available nutrient status : Available N, P and K contents were significantly higher with application of FYM @ 2.5 and $5 \mathrm{t} \mathrm{ha}^{-1}$ compared with control and lower doses of inputs (Table 1). Periodical addition of mineral (N40) and organic fertilizers (M2.5 and 5 with $\mathrm{N}$ ) increased significantly the available nitrogen content in assessed time period compared with control. The positive balance of available nitrogen in the FYM amended plots could be attributed to positive balance of SOC $\left(r=0.49^{* *}\right)$. The Olson P content was higher for FYM @ 5 t ha $^{-1}$ as compared to 
Table 1 : Effect of manure and urea treatments on soil organic carbon, microbial biomass carbon (MBC), cation exchange capacity (CEC) and available nutrient status

\begin{tabular}{|c|c|c|c|c|c|c|}
\hline Treatments & $\operatorname{sOC}\left(\mathrm{g} \mathrm{kg}^{-1}\right)$ & $\operatorname{MBC}\left(\mu g g^{-1}\right)$ & $\operatorname{CEC}\left(\mathrm{C} \mathrm{mol} \mathrm{kg}{ }^{-1}\right)$ & Avail. N (kg ha $\left.{ }^{-1}\right)$ & Avail. $P\left(\mathrm{~kg} \mathrm{ha}^{-1}\right)$ & Avail. K (kg ha $\left.{ }^{-1}\right)$ \\
\hline Control & 1.12 & 14.11 & 6.45 & 54.36 & 13.42 & 218.10 \\
\hline $\mathrm{M}_{0} \mathrm{~N}_{20}$ & 1.51 & 22.65 & 6.68 & 74.84 & 13.85 & 233.18 \\
\hline $\mathrm{M}_{0} \mathrm{~N}_{40}$ & 1.81 & 25.26 & 6.73 & 87.70 & 13.94 & 237.95 \\
\hline $\mathrm{M}_{2.5} \mathrm{~N}_{0}$ & 1.87 & 39.96 & 7.13 & 92.91 & 16.32 & 260.10 \\
\hline $\mathrm{M}_{2.5} \mathrm{~N}_{20}$ & 2.03 & 53.01 & 7.21 & 95.00 & 16.08 & 263.40 \\
\hline $\mathrm{M}_{2.5} \mathrm{~N}_{40}$ & 2.11 & 56.40 & 7.06 & 96.10 & 17.90 & 266.70 \\
\hline $\mathrm{M}_{5.0} \mathrm{~N}_{0}$ & 2.29 & 58.15 & 7.47 & 98.41 & 20.42 & 279.05 \\
\hline $\mathrm{M}_{5.0} \mathrm{~N}_{20}$ & 2.47 & 65.12 & 7.42 & 100.62 & 20.01 & 285.40 \\
\hline $\mathrm{M}_{5.0} \mathrm{~N}_{40}$ & 2.93 & 67.43 & 7.37 & 106.21 & 21.10 & 287.90 \\
\hline $\operatorname{LSD}(0.5)$ & 0.39 & 11.39 & 0.59 & 23.69 & 5.17 & 41.78 \\
\hline
\end{tabular}

control and lower doses of inputs. The maximum content of available N, P and K was observed in FYM @ 5 tha $^{-1}+40 \mathrm{~kg} \mathrm{~N} \mathrm{ha}^{-1}$ (106.21 $\mathrm{N} \mathrm{kg} \mathrm{ha}^{-1} ; 21.10 \mathrm{P}_{2} \mathrm{O}_{5} \mathrm{~kg} \mathrm{ha}^{-1}$ and $287.90 \mathrm{~K}_{2} 0 \mathrm{~kg} \mathrm{ha}^{-1}$ ), while minimum was observed in control (Table 1).

Application of fertilizers and manures resulted in significant improvement in the available nitrogen contents. So, it is clear that application of organic manures in combination with chemical fertilizers increased the available nitrogen in soil, which may be attributed to mineralization of nitrogen from inhabitant sources during decomposition. Increasing organic amendments and decreasing application of inorganic fertilizers can optimize soil microorganisms, thus promoting the internal circulation of soil microenvironment nutrients (Germaine et al., 2010). Aoyama and Kumakura (2001) also reported similar results in Ando soil induced by mineral fertilizer and cattle manure applications leading to increase in organic matter.

The depletion of Olsen-P from its initial value was observed with control and $\mathrm{N}$ application. Application of farmyard manure along with $\mathrm{N}$ increased Olsen- $\mathrm{P}$ because of $\mathrm{P}$ applied through FYM, and possibly by reduced fixation (Gupta et al., 1988), which might be due to the fact that the major $P$ fraction supplemented through FYM is in the organic pool that mineralized gradually with time (Singh et al., 2004). The application of FYM in soil helped in increasing the available $P$ in the soil by mineralization or solubilizing the native $P$ reserves (Walia et al., 2010). With N + FYM, the available K content in the surface layer increased after 25 crop cycles. Soil available $\mathrm{K}$ content showed differential changes depending on the probable release of nonexchangeable $\mathrm{K}$ from the soil profile. Available $\mathrm{K}$ depletion in the $0-15 \mathrm{~cm}$ soil layer was observed only with unfertilized control and lower doses of $\mathrm{N}$. Application of FYM resulted in increase in available $\mathrm{K}$ due to higher non-exchangeable $\mathrm{K}$ release from the soils (Bhattacharyya et al., 2006). Singh et al. (2014) reported significant build up of available $\mathrm{K}$ with the application of organic manures which may be attributed to solubilising action of certain organic acids produced during decomposition of organic manures over chemical fertilizers.
Soil microbiological properties : Soil microbial biomass (MBC) represents $1-4 \%$ of total $C$ and as living part of SOM it is responsible for nutrient transformation and storage (Nieder et al., 2008). MBC content within the assessed time period ranged from 14.11 to $67.43 \mu \mathrm{g} \mathrm{g}^{-1}$ soil; low MBC was found in the control (Table 1). Maximum values of $M B C$ were determined in treatment with FYM. Application of FYM and FYM $+\mathrm{N}$ increased MBC significantly compared with the control and nitrogenous fertilizer. The results also confirm the previous studies which document that microbial biomass were clearly higher in soils receiving farmyard manure (Hao et al., 2008, Liu et al., 2010) and FYM + mineral N (Mandal et al., 2007). Dehydrogenase activity is only present in viable cells and reflects the total range of oxidative activity of soil microflora (Kanchikerimath and Singh, 2001). Dehydrogenase activity varied from 48.46 to $91.20 \mathrm{\mu g} \mathrm{TPF} \mathrm{g}^{-1} \mathrm{~d}^{-1}$ (Fig. 6a) and was significantly higher in FYM @ 2.5 and 5 t ha $^{-1}$ with or without nitrogen as compared to control. Similarly, Basha et al. (2017) also observed higher dehydrogenase and phosphatse activity with various combination of organic manures. Mandal et al. (2007) showed that easily decomposable components of crop residues which were contributed from crop may have a strong effect on dehydrogenase activity and metabolism of soil microorganisms. Fluorescein diacetate (FDA) hydrolysis activity varied from 3.07 to $4.22 \mu \mathrm{g}$ Fluor. $\mathrm{g}^{-1} \mathrm{hr}^{-1}$, being significantly higher as in DHA with FYM @ 2.5 and 5 t ha $^{-1}$ with or without nitrogen as compared to control (Fig. 6a). Acid phosphatase activity (Fig. 6b) varied from 7.58 to $17.93 \mu \mathrm{PNP} \mathrm{g}^{-1}$ hr $\mathrm{r}^{-1}$ (Fig. 6b). Application of FYM @ $5 \mathrm{tha}^{-1}+40 \mathrm{~kg} \mathrm{~N}^{-1} \mathrm{~h}^{-1}$ resulted in higher activity than other treatments. Alkaline phosphatase activity ranged from 29.24 to $64.22 \mu \mathrm{g}$ PNP g ${ }^{-1} \mathrm{hr}^{-1}$ and was significantly higher in all the treatments as compared to control (Fig. 6b). $\beta$-D-glucopyranosidase and $\beta$-D-galactopyranosidase activity also followed a similar pattern, varying from 3.19 to 4.95 $\mu \mathrm{g} P N P \mathrm{~g}^{-1} \mathrm{hr}^{-1}$ and 19.89 to $44.29 \mu \mathrm{g}$ PNP $\mathrm{g}^{-1} \mathrm{hr}^{-1}$, respectively (Fig.6c).

The potential metabolic activities of soil can go through the assay values of soil enzymes (Fig. 6). DHA and FDA reflects 

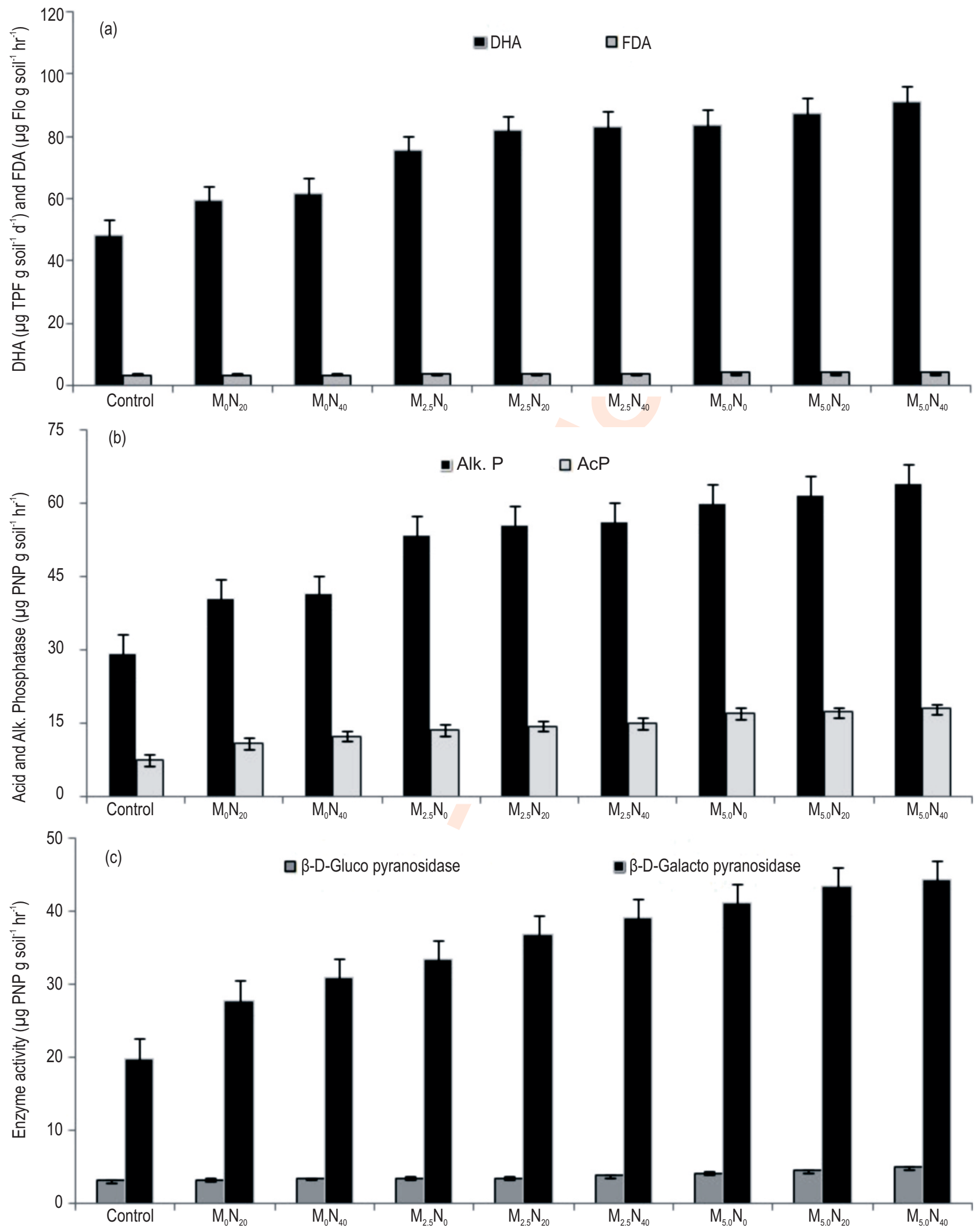

Fig. 6 : Effect of manure and urea treatments on (a) dehydrogenase activity (DHA), flurescein di acetate (FDA); (b) acid and alkaline phosphatase (AcP and Alk P) and (c) $\beta$-D-Gluco pyranosidase and $\beta$-D-Galacto pyranosidase actvity in soil. Error bars indicate standard deviation. 
the metabolic activity of soil. DHAis present in enzyme systems of all microorganisms, and play an essential role at initial stages of oxidation of soil organic matter by transferring electrons or hydrogen from substrate to acceptors. FDA is a sensitive indicator of ecosystem activity; its disturbance reflects protease, lipase and esterase activities of soil (Tripathi et al., 2006). Hydrolysis of fluorescein diacetate (FDA) is performed by a variety of enzymes including esterase, proteases and lipases (Niakeen et al., 2015). Moreover, according to Komilis et al. (2011), FDA hydrolysis can be used as an indicator of microbial activity in relation to the state of soil environment. FYM improved both the quantity and quality of soil organic matter. Moreover, addition of mineral fertilizer with FYM increased the effect of organic manure on organic $\mathrm{C}$ and $\mathrm{N}$ content in soil and soil enzyme activity (Šimon and Czakó, 2014).

As pH of soil lies within alkaline range (7.1 to 8.2), it might be expected that alkaline phosphatase activity was dominant over acid phosphatase in these soil. Saha et al. (2008) reported 23 fold higher value of alkaline phosphatase as compared to acid phosphatase in inorganic and organic amended soils. Alkaline phosphatase activity of soil was significantly more visualized through organic manure application rather than acid phosphatase (Basak et al., 2016). Other than phosphatase activity, organic manure enhanced soil biological activity (microbial biomass and release of enzymes), indicating that the use of manures in crop production is an affordable and sustainable agricultural production system (Antonious et al., 2020).

$\beta$-D-glucopyranosidase and $\beta$-D-galactopyranosidase actvity reflects degradation of cellulose to glucose; acid and alkaline phosphatase (AcP / AkIP) mineralize organic phosphorous phosphate by hydrolyzing phosphoric (mono) ester bonds under acidiclalkaline conditions. Abundance of cellulose in soil at integrated treated plots visualized higher $\beta$-glu activity (AcostaMartínez et al., 2008). A significant promotion of $\mathrm{N}$ addition on $\mathrm{P}$ and $\mathrm{N}$-cycling enzymes has been found in some terrestrial ecosystems (Steward et al., 2008 and Jing et al., 2016). Combining organic matter/crop straw residues with chemical fertilization could be an important strategy for increasing labile fractions of soil organic matter, improving soil enzymatic activities and improving the quality of organic matter (Zhang et al., 2020).

Over 25 years of pearl millet cultivation in arid soils, the treatment receiving FYM along with optimal dose of chemical fertilizer provided highest yield sustainability of pearl millet and improved soil fertility. These findings showed that the integration of FYM @ $2.5 \mathrm{t} \mathrm{ha}^{-1} \mathrm{yr}^{-1}$ with $20 \mathrm{~kg} \mathrm{~N} \mathrm{ha}^{-1}$ sustained higher productivity to modest economic status farmers in a delicate ecosystem with the available minimum resources for livelihood. It not only restore the original fertility status of soil but also improved nutrient status and soil biological health which may be advantageous for sustaining the productivity of the system in arid environment.

\section{References}

Acosta-Martı'nez, V., D. Acosta-Mercado, Sotomayor-Ramı'rez and L. Cruz-Rodri'guezc: Microbial communities and enzymatic activities under different management in semiarid soil. Appl. Soil Ecol., 38, 249-260 (2008).

Antonious, G.F., E.T. Turley and M.H. Dawood: Monitoring soil enzymes activity before and after animal manure application. Agriculture, 10, 166 (2020). doi:10.3390/agriculture10050166

Aoyama, M. and N. Kumakura: Quantitative and qualitative changes of organic matter in an Ando soil induced by mineral fertilizer and cattle manure applications for 20 years. Soil Sci. PI. Nutr., 47, 241-252 (2001).

Aulakh, M.S., T.S. Khera, J.W. Doran and K.F. Bronson: Managing crop residue with green manure, urea, and tillage in a rice-wheat rotation. Soil Sci. Soc. Am. J., 65, 820-827 (2001).

Basak, N., A. Datta, T. Mitran, B. Mandal and P.K. Mani: Impact of organic and mineral inputs onto soil biological and metabolic activities under a long-term rice-wheat cropping system in sub-tropical Indian Inceptisols. J. Environ. Biol., 37, 83-89 (2016).

Basha, S. J., R. Basavarajappa, G. Shirnalli and H.B. Babalad: Soil microbial dynamics and enzyme activities as influenced by organic and inorganic nutrient management in vertisols under aerobic rice cultivation. J. Environ. Biol., 38, 131-138 (2017).

Bhattacharyya, R., V. Prakash, S. Kundu, A.K. Srivastva and H.S. Gupta: Potassium balance as influenced by farmyard manure application under continuous soybean-wheat cropping system in a Typic Haplaquept. Geoderma, 137, 155-160 (2006).

Böhme, L., U. Langer and F. Böhme: Microbial biomass, enzyme activities and microbial community structure in two European longterm experiments. Agric. Ecosys. Environ., 109, 141-152 (2005).

Casida, L.E., D. Klein and T. Santoro: Soil dehydrogenase activity. Soil Sci., 98, 371-376 (1964).

Chang, E., R. Chung and Y. TSAI.: Effect of different application rates of organic fertilizer on soil enzyme activity and microbial population. Soil Sci. Pl. Nut., 53, 132-140 (2007).

Denison R.F., C.B. Dennis and E.K. Thomas: Crop yields over the first nine years of LTRAS, a long-term comparison of field crop systems in a Mediterranean climate. Field Crops Res., 86, 267-277 (2004).

Eivazi, F. and M.A. Tabatabai: Phosphatase in soils. Soil Biol. Biochem., 9, 167-172(1977).

FAO. Sustainability Pathways: Smallholders and Family Farmers. Available online at: http://www.fao.org/fileadmin/templates/nr/ sustainability_pathways/docs/Factsheet_SMALLHOLDERS.pdf. (2012).

Germaine, K.J., S. Chhabra, B. Song, D. Brazil and D.N. Dowling: Microbes and sustainable production of biofuel crops: A nitrogen perspective. Biofuels, 16, 196-203 (2010).

Giacometti, C., L. Cavani, G. Baldoni, C. Ciavatta, C. Marzadori and E. Kandeler.: Microplate-scale fluorometric soil enzyme assays as tools to assess soil quality in a long-term agricultural field experiment. Appl. Soil Ecol., 75, 80-85 (2014).

Gomez, K.A. and A.A. Gomez: Statistical procedures for agricultural research. $2^{\text {nd }}$ Edn., John Wiley and Sons, New York (1984).

Green, V.S., D.E. Stott and M. Diack: Assay for fluorescein diacetate hydrolytic activity: Optimization for soil samples. Soil Biol. Biochem., 38, 693-701 (2006).

Guibert, $\mathrm{H}$.: Carbon content in soil particle size and consequence on cation exchange capacity of Alfisols. Commun. Soil Sci. Plant. 
Anal., 30, 2521-2537 (1999).

Gupta, A.P., R.S. Antil and R.P. Narwal: Effect of farmyard manure on organic carbon, available $\mathrm{N}$, and $\mathrm{P}$ content of soil during different periods of wheat growth. J. Indian Soc. Soil Sci., 262, 269-273 (1988).

Hao, X.H., S.L. Liu, J.S. Wu, R.G. Hu, C.L. Tong and Y.Y. Su: Effect of long-term application of inorganic fertilizer and organic amendments on soil organic matter and microbial biomass in three subtropical paddy soils. Nutr. Cycl. Agroecosys., 81, 17-24 (2008).

Jackson, M.L.: Soil Chemical Analysis. Prentice Hall of India Pvt. Ltd., New Delhi (1962).

Jing, X., X.X. Yang, F. Ren, H.K. Zhou, B. Zhu and J.S. He: Neutral effect of nitrogen addition and negative effect of phosphorus addition on topsoil extracellular enzymatic activities in an alpine grassland ecosystem. Appl. Soil Ecol., 107, 205-213 (2016).

Kanchikerimath, M. and D. Singh: Soil organic matter and biological properties after 26 years of maize-wheat-cowpea cropping as affected by manure and fertilization in a Cambisol in semiarid region of India. Agric. Ecosys. Environ., 86, 155-162 (2001).

Katterer, T., Ma Bolinder, O. Andren and L. Menichetti: Roots contribute more to refractory soil organic matter than above-ground crop residues, as revealed by a long-term field experiment. Agric. Ecosys. Mngt., 141, 184-192 (2011).

Komilis, D., I. Kontou and S. Ntougias: A modified static respiration assay and its relationship with an enzymatic test to assess compost stability and maturity. Bioresour. Technol., 102, 5863-5872 (2011).

Liu, E., C. Yan, X. Mei, W. He, S.H. Bing, L. Ding, Q. Liu, S. Liu and T. Fan: Long-term effect of chemical fertilizer, straw, and manure on soil chemical and biological properties in northwest China. Geoderma, 158, 173-180 (2010).

Lowder, S., J. Skoet and T. Raney.: The number, size and distribution of farms, smallholder farms, and family farms worldwide. World Dev., 87, 16-29. (2016).

Mandal, A., A.K. Patra, D. Singh, A. Swarup and R.E. Masto: Effect of long-term application of manure and fertilizer on biological and biochemical activities in soil during crop development stages. Bioresour. Technol., 98, 3585-3592 (2007).

Manna, M.C., A. Swarup, R.H. Wanjari, H.N. Ravankar, B. Mishra, M.N. Saha, Y.V. Singh, D.K. Sahi, and P.A. Sarap: Long-term effect of fertilizer and manure application on soil organic carbon storage, soil quality and yield sustainability under subhumid and semi-arid tropical India. Field Crops Res., 93, 264-280 (2005).

Moore, S.R.: Energy efficiency in small-scale biointensive organic onion production in Pennsylvania, USA. Renew. Agricult. Food Syst., 25, 181-188 (2010).

Niakeen, M., A.H. Nafez, B. Bina, B.F. Nabavi and A. Hassanzadeh: Respiration and enzymatic activities as indicators of stabilization of sewage sludge composting. Waste Manag., 39, 104-110 (2015).

Nieder, R., T. Harden, R. Martens and D.K. Benbi: Microbial biomass in arable soils of Germany during the growth period of annual crops. J. Plant Nutr., 171, 878-885 (2008).

Olsen, S.R., C.V. Cole, F.S. Watanabe and L.A. Dean: Estimation of available phosphorus in soils by extraction with $\mathrm{NaHCO}_{3}$. USDA Cir. 939. U.S. Washington (1954).

Saha, S., V. Prakash, S. Kundu, N. Kumar and B.L. Mina: Soil enzymatic activity as affected by long term application of farm yard manure and mineral fertilizer under a rainfed soybean-wheat system in NW Himalaya. Eur. J. Soil Biol., 44, 309-315 (2008).
Saxena, A., Praveen-Kumar, D.V. Singh, N.R. Panwar and N.L. Joshi: Deciphering yield sustainability of high yielding pearl millet varieties in arid environment. Natl. Acad. Sci. Lett., 41, 75-79 (2018).

Schröder, J.: Revisiting the agronomic benefits of manure: A correct assessment and exploitation of its fertilizer value spares the environment. Bioresour. Technol., 96, 253-261 (2005).

Selvakumari, G., M. Bhaskar, D., Jayanthi and K.K. Mathan: Effect of integration of fly ash with fertilizers and organic manure on nutrient availability, yield and nutrient uptake of ricein alfisols. J. Indian Soc. Soil Sci., 48, 68-278 (2000)

Shi, W.: Agricultural and Ecological Significance of Soil Enzymes: Soil Carbon Sequestration and Nutrient Cycling. In: Soil Enzymology (Eds.: G. Shukla and A. Varma). Springer, Berlin/Heidelberg, Germany, pp. 43-60 (2011).

Šimon, T. and A. Czakó: Influence of long-term application of organic and inorganic fertilizers on soil properties. Plant Soil Environ., 60, 314-319 (2014).

Singh, M., S. Ram, R.H. Wanjari and P. Sharma: Balance and forms of potassium under rice-wheat system in a 40-year-old long-term experiment on Mollisols of Pantnagar. J. Indian Soc. Soil Sci., 62 , 38-44 (2014)

Singh, R.P., S.K. Das, U.M. Bhaskara Rao and M. Narayana Reddy: Towards Sustainable Dryland Agricultural Practices. Technical Bulletin. Central Research Institute for Dryland Agriculture, Hyderabad, India (1990).

Singh, S., R.N. Singh, J. Prasad and B. Kumar: Effect of green manuring, manure and bio-fertilizer in relation to fertilizer $\mathrm{N}$ on yield and major nutrient uptake by upland rice. J. Indian Soc. Soil Sci., 50, 313-314 (2002).

Singh, Y., Bijay-Singh, J.K. Ladha, C.S. Khind, R.K. Gupta, O.P. Meelu and E. Pasuquin: Long-term effects of organic inputs on yield and soil fertility in rice- wheat rotation. Soil Sci. Soc. Am. J., 68, 845-853 (2004).

Stevend, A., C. Claudiai and T. Kathleenk: Microbial activity and soil respiration under nitrogen addition in Alaskan boreal forest. Global Change Biol., 14, 1156-1168 (2008).

Stocking, W. A.: Tropical Soils and Food Security: The Next 50 Years. Science, 302, 1356-1359 (2003).

Subbiah, B.V. and G.L. Asija: A rapid procedure for the estimation of available nitrogen in soils. Curr. Sci., 25, 259 (1956).

Sui, X., H. Guo, Z. Li, M. Wang, Y. Wang and X. Zhang: Effect of corn straw manure as dairy manure on productivity and profitability of wheat at Huang-Huai-Hai plain. J. Environ. Biol., 40, 441-447 (2019).

Tabatabai, M.A. and J.M. Bremner: Use of p-nitrophenyl phosphate for assay of soil phosphatase activity. Soil Biol. Biochem., 1, 301-307 (1969).

Tiwari, V.N., H. Singh and R.M. Upadhyay: Effect of biocides organic Manure and blue green algae on yield and yield attributing characteristics of rice and soil productivity under sodic soil conditions. J. Indian Soc. Soil Sci., 49, 332-336 (2001).

Tripathi, R., A.K. Nayak, P. B hattacharyya, A.K. Shukla, M. Shahid, P. Raja, B.B. Panda, S. Mohanty, A. Kumar and V.K. Thilagam: Soil aggregation and distribution of carbon and nitrogen in different fractions after 41 years long-term fertilizer experiment in tropical rice-rice system. Geoderma, 213, 280-286 (2014).

Tripathi, S., S. Kumari, A. Chakraborty, A. Gupta, K. Chakrabarti and B.K. Bandyapadhyay: Microbial biomass and its activities in salt 
affected coastal soils. Biol. Fert. Soils, 42, 273-277 (2006).

USEPA: Test methods for evaluating solid waste. EPA Report SW-846. Office of Solid Waste and Emergency Response, Washington, DC (1990).

Vance, E.D., P.C. Brookes and D.S. Jenkinson: An extraction method for measuring soil microbial biomass C. Soil Biol. Biochem., 19, 703-707 (1987).

Walia, M.K., S.S. Walia and S.S. Dhaliwal: Long-term effect of integrated nutrient management of properties of Typic Ustochrept after 23 cycles of an irrigated rice (Oryza sativa L.) - wheat (Triticum aestivum L.) system. J. Sustain. Agr., 34, 724-743 (2010).

Walkley, A. and J.A. Black: Estimation of soil organic carbon by chromic acid titration method. Soil Sci., 17, 29-38 (1934).

Wanjari, R.H., M.V. Singh and P.K. Ghosh: Sustainable yield index: An approach to evaluate the sustainability of long-term intensive cropping systems in India. J. Sustain. Agr., 24, 39-56 (2004).

Wei, M., G. Hu, H. Wang, E. Bai, Y. Lou, A. Zhang and Y. Zhuge: 35 years of manure and chemical fertilizer application alters soil microbial community composition in a Fluvo-aquic soil in Northern China. Eur. J. Soil. Biol. 82, 27-34 (2017).

Ye, L., X. Zhao, E. Bao, J. Li, Z. Zou and K. Cao: Bio-organic fertilizer with reduced rates of chemical fertilization improves soil fertility and enhances tomato yield and quality. Sci. Rep., 10, 177 (2020).

Zhang, L., X. Chen, Y. Xu, M. Jin, X. Ye, H. Gao, W. Chu, J. Mao and M.L. Thompson: Soil labile organic carbon fractions and soil enzyme activities after 10 years of continuous fertilization and wheat residue incorporation. Sci. Rep., 10, 11318 (2020). 